\title{
GRANULITE/CHARNOCKITE FROM THE JUIZ DE FORA DOMAIN, CENTRAL SEGMENT OF THE BRASILIANO RIBEIRA BELT
}

\author{
BEATRIZ PASCHOAL DUARTE ${ }^{1}$, MONICA HEILBRON ${ }^{1}$ AND MARIO DA COSTA CAMPOS NETO ${ }^{3}$
}

\begin{abstract}
The Ribeira Belt is the product of the last stage of Brasiliano collage in southeastern Brazil. Its Ocidental Terrane comprises the reworked margin of the San Francisco Craton, which is composed by two thrust sheets: the Andrelandia and the Juiz de Fora domains (Heilbron et al. 1998). The latter includes three different tectonically bounded litho-stratigraphic units: pre-1.8 Ga. granulite facies orthogneisses; post-1.8 Ga. metasedimentary rocks; and Brasiliano-Pan-African granitoids and charnockitoids. Each unit comprises a characteristic type of granulite/charnockite. The pre-1.8 Ga. unit is composed of basic to acid orthopyroxene-bearing orthogneisses with a granoblastic fabric. Field and petrological data indicate that granulite metamorphism is the result of infiltration of $\mathrm{CO}_{2}$-rich fluids. A late mylonitic foliation and retrogressive mineral products are contemporaneous to the Brasiliano-Pan-African tectonic stacking. The paragneisses display granulite facies parageneses within a foliated and/or mylonitic structure and show features of in situ migmatization caused by the breakdown of biotite. Charnockite bodies occur as garnet-(orthopyroxene)-bearing leucosomes within the paragneisses and also as isotropic to slightly foliated individualized igneous bodies with enclaves of the other units. They are interpreted as the product of anatexis of the paragneisses with minor contributions of the prthogranulites. Granulite facies metamorphism of the paragneisses, and anhydrous melting were caused by tectonic stacking related to the Brasiliano collage.
\end{abstract}

Keywords: Precambrian; Ribeira Belt; Granulite; Igneous Charnockite

INTRODUCTION The term Juiz de Fora was first used by Ebert (1955) who defined the Juiz de Fora Series as composed of paragneisses with granulite facies parageneses, which crop in southeast Minas Gerais.

The identification of associated granulite facies orthogneisses led several authors to include these rocks under the same denomination (Juiz de Fora Series or Complex; Cordani et al. 1973; Fonseca et al. 1979; Oliveira 1980, 1981, 1982, 1983; Machado Filho et al. 1983; Barbosa and Grossi Sad 1983a, 1983b, 1983c; Grossi Sad and Barbosa 1985; Pinto 1991).

In several areas of the Ribeira Belt it was verified that only orthogneisses bore granulite facies parageneses. This fact induced some authors to use the denomination of Juiz de Fora to group these rocks (Figueiredo et al. 1989; Campos Neto \& Figueiredo 1990; Figueiredo and Campos Neto 1993; Teixeira and Figueiredo 1991; Heilbron 1993, 1995; Nogueira 1994; Nogueira and Trouw 1993; Heilbron et al. 1995, 1996; Machado et al. 1996).

Therefore, through the last two or three decades, the practical use of the denomination of Juiz de Fora has been gradually drifting apart from the original definition leading to a strong association of the term with the granulite facies ortho-derived gneisses.

$\mathrm{U}-\mathrm{Pb}$ zircon analyses on charnockitic orthogneisses yielded ages of » $2.0 \mathrm{Ga}$, which were interpreted as the age of the protolith (Machado et al., 1996). $\mathrm{Pb}-\mathrm{Pb}$ and U-P analyses were carried out on detrital zircons from quartzites of the metasedimentary unit and the obtained ages of $2.0 \mathrm{Ga}$. indicate a Paleoproterozoic crust as its source (Valladares et al. 1997, 2000).

In order to avoid further confusion, this work uses the term Juiz de Fora Complex to name the group of orthogneisses with granulite facies diagnostic parageneses. However, besides the granulitic orthogneisses of the Juiz de Fora Complex, other distinct groups of granulite were identified in the study area and data point to the existence of three different granulite litho-stratigraphic units, each one formed by a distinct petrological process. The present work aims to present and characterize each of these units.

\section{STRUCTURAL ORGANIZATION OF THE RIBEIRA BELT}

The Brasiliano-Pan-African Ribeira Belt is located on the south/ southeast margin of the São Francisco Craton and its crustal organization is defined as follows (Heilbron et al., 1998) (Fig. 1): 1) the Occidental Terrane comprises two crustal scale thrust sheets (Andrelandia and Juiz de Fora domains) which are considered as the Neoproterozoic products of the reworked cratonic margins; 2) the Oriental Terrane constitutes another microplate (part of the Congo Plate), which was accreted during the Brasiliano Orogeny and comprises the following domains: a) the Costeiro or Serra do Mar Domain; b) the Ribeira Magmatic Arc (Tupinambá et al., 1998); c) the Paraíba do Sul Klippe, which is the uppermost domain in this segment of the belt; and d) the Cabo Frio Domain, which occupies a restrict portion at the coast of Rio de Janeiro and is a product of relatively late amalgamation (Schmitt et al. 1999).
GEOLOGY OF THE JUIZ DE FORA DOMAIN Structural Organization, Lithological Units, Metamorphism and Magmatism The Juiz de Fora Domain (JFD) includes three different litho-stratigraphic units: pre-1.8 Ga granulitic orthogneisses (Juiz de Fora Complex); post-1.8 Ga metasedimentary rocks; and Brasiliano-Pan-African granitoids and charnockitoids (Duarte et al. 1994; Duarte 1998) (Fig. 2). The pre- and post-1.8 Ga units and also some of the granitoid rocks are tectonically bounded and occur as thrust sheets within this domain. As a result, the JFD is characterized by imbrications of lithological units and strong mylonitization. Further, stratigraphic correlations with units of the Andrelandia Nappe or the cratonic area are still a subject of discussion. Field and petrographic data indicate that, with the exception of the granitoid rocks, all lithotypes display granulite facies (or anhydrous) mineral parageneses. Brasiliano-Pan-African magmatism is represented by I- and S-type, syn-collisional, granitoids or charnockitoids (Duarte 1998; Valladares et al. 2000) and I-type post-collisional leucogranite (Nogueira 1994). Within all three different lithostratigraphic units, there was identified a characteristic type of granulite/charnockite, each displaying features of having been generated by a distinct petrological process.

GRANULITE/CHARNOCKITE OF THE JUIZ DE FORA DOMAIN Pre-1.8 Ga Granulites: the Juiz de Fora Complex The Juiz de Fora Complex consists of granulite facies orthogneisses with lithotypes of a wide range of composition, from basic to acid. Although noritic and quartz-rich granulites ( quartz $>$ $80 \%$ volume) occur, enderbitic, charno-enderbitic and charnockitic compositions are the most widespread. Strong deformation processes together with high-grade metamorphism caused obliteration of original textures and structures and the current configuration comprises bands, lenses and/or boudins of norites within quartz noritic to charnoenderbitic orthogneisses (Fig. 3A). In spite of obliteration of primary structures, field data indicate that charnockitic and quartz-rich charnockitic types are intrusive within the other lithotypes (Fig. 3B). The rocks of the Juiz de Fora Complex are greenish or brown. Banding is common and migmatitic structures, when present, display green leuco-, meso- and melanosomes, suggesting that in situ anatexis took place before granulite facies metamorphism. Granulites become greyish protomylonites, mylonites or ultramylonites when close to the thrust planes developed during the Brasiliano Orogeny. Together with petrographic data, this indicates that the Brasiliano metamorphism produced retrogressive mineral parageneses after the granulite facies ones. Hydrated minerals such as hornblende and / or biotite occur at the borders of and within pyroxene grains, attesting the development of retrogressive reactions. These new minerals are usually oriented along the younger foliation of mylonitic nature.

Post-1.8 Ga Granulites: the metasedimentary unit This unit comprises quartz-feldspathic, pelitic and semipelitic gneisses with minor quartzite, feldspathic quartzite, calcsilicate rocks, and associated 

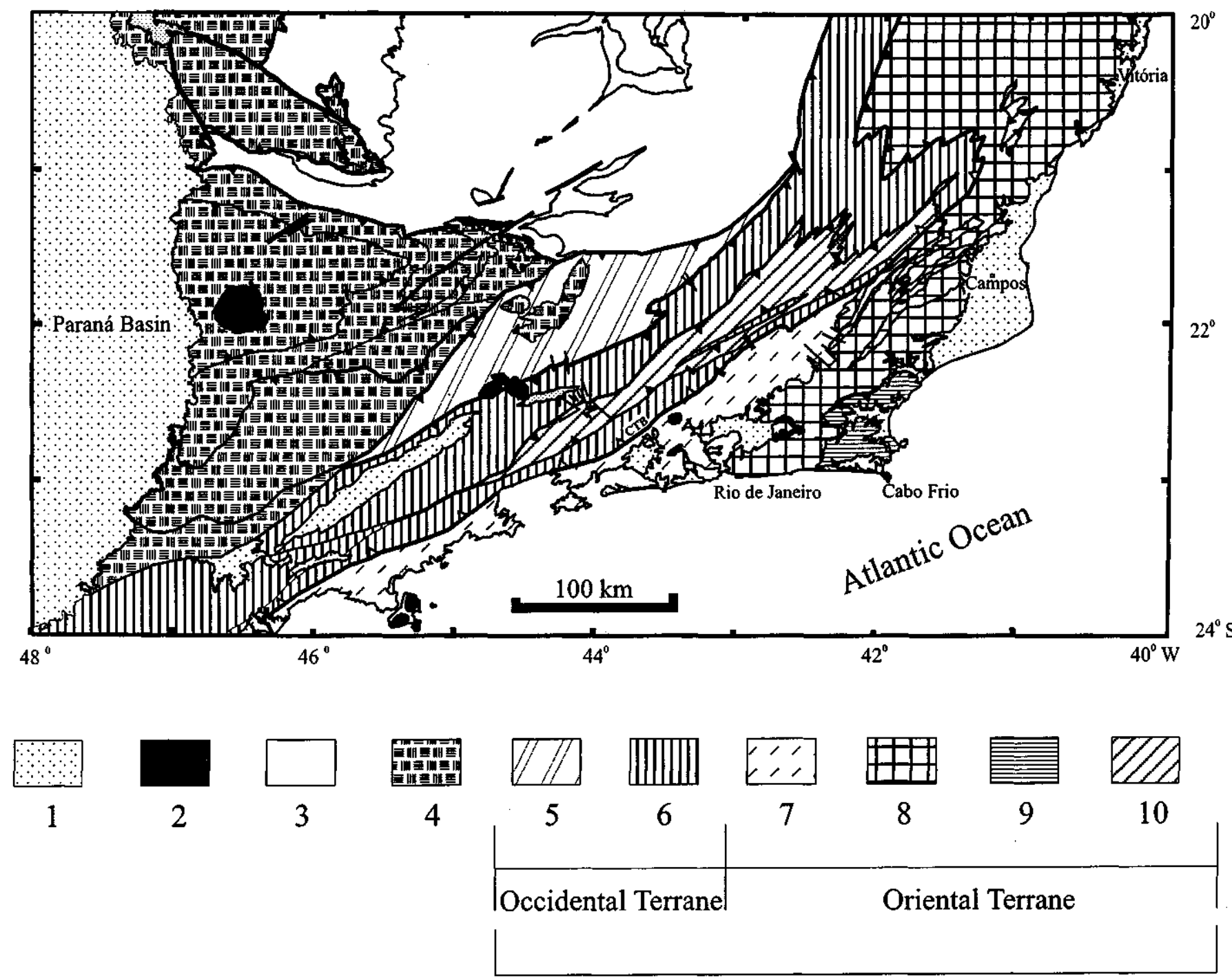

\section{Ribeira Belt (central segment)}

Figure 1-Tectonic Map of southeastern Brazil (Heilbron et al. 1998).1- Phanerozoic cover; 2 - Cretaceous / Tertiary alkaline rocks; 3 - São Francisco Craton and foreland domains; 4 - Brasilia belt nappes domain; 5 - Andrelândia domain; 6 - Juiz de Fora domain; 7 - Ribeira magmatic arc; 8 - Costeiro domain; 9 - Cabo Frio domain; 10 - Paraiba do Sul Klippe.

mafic bodies. The subordinate lithotypes occur as lenses and/or boudin shaped-like bodies within the paragneisses. All these rocks are disposed along thrust sheets, which are interlayered with the orthogranulites of the Juiz de Fora Complex. Contacts between two distinct paragneisses or between paragneisses and quartzites within the same thrust sheet are usually gradational. Close to the shear zones, these rocks show mylonitic foliation. The paragneisses of semipelitic composition are strongly migmatized and the resultant structures are mainly of stromatic type (Fig. 3C). Garnet and orthopyroxene are common mineral phases of the leucosome of these migmatites, suggesting the breakdown of biotite as the main $\mathrm{H}_{2} \mathrm{O}$ source of the migmatization/dehydration process. Mineral parageneses with orthopyroxene occur in the quartz-feldspathic and the semipelitic gneisses. Associated with evidences of biotite breakdown, this feature indicates that the rocks were metamorphosed under granulite facies conditions.

Brasiliano-Pan-African Charnockite: Salvaterra Charnoenderbite The Salvaterra Charno-enderbite is a garnet-bearing plutonic parautochthonous body which crops out in Salvaterra district of the city of Juiz de Fora, in close association with the semipelitic paragneisses of the Juiz de Fora Domain. It consists of an isotropic to slightly foliated body with a spotted structure of alternating green and grey colors, reflecting, probably, $a_{H 2 O}$ gradients or heterogeneous fluid phase distribution during its magmatic evolution: green portions reflect anhydrous and/or $\mathrm{H}_{2} \mathrm{O}$-poor fluid phase conditions; grey portions reflect hydrated and/or $\mathrm{H}_{2} \mathrm{O}$-rich fluid phase conditions. Field data indicate that the contact between paragneisses and Salvaterra charnoenderbite is of gradational kind, developing through the following stages: 1) incipient to strong migmatization of paragneiss, forming mainly stromatic migmatite with leucosome structurally and compositionally similar to the Salvaterra Charno-enderbite (Fig. 3C); 2) diatexite, also structurally and compositionally similar to the Salvaterra Charno-enderbite, with schlieren structures composed mainly of biotite and garnet (Fig. 3D); Salvaterra Charno-enderbite with enclaves of paragneiss, calcsilicate rock and orthogranulite of the Juiz de Fora Complex (Figs. 3E and 3F). Oriented schlieren structures, which parallel the main regional foliation, resemble ghost features that were inherited from the pre-existing gneiss. Intrusive contacts hardly occur. The rock is medium to coarse grained and shows granoblastic to grano-porphyroblastic textures. Locally, igneous porphyritic texture is preserved with phenocrysts of feldspar (Fig. 4A), garnet and orthopyroxene. Close to the thrust planes, the Salvaterra Charnoenderbite acquires a mylonitic texture, which shows that this body was at least locally affected by the thrust tectonism that evolved within the Juiz de Fora Domain.

METAMORPHIC EVOLUTION OF THE ROCKS FROM THE JUIZ DE FORA DOMAIN Two metamorphic events were 


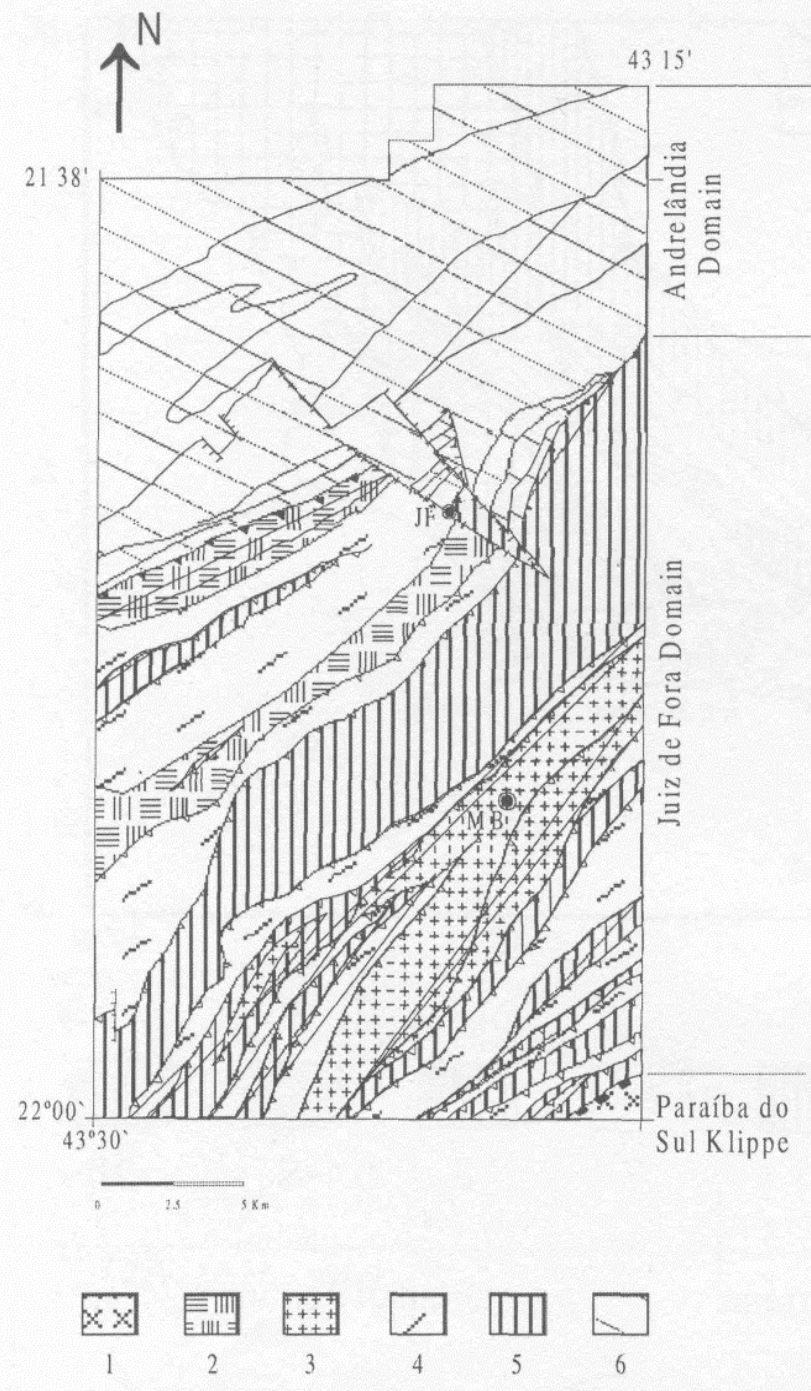

Figure 2-Geologic map of the Juiz de Fora region (modified from Duarte et al. 1994). Ortho- and paragneisses, Paraiba do Sul Klippe (1); Juiz. de Fora domain: Salvaterra Charno-enderbite (2); Matias Barbosa Intrusive Suite (3); Post-1.8 Ga metasedimentary rocks (4); Granulite fades orthogneisses, Juiz de Fora Complex (5); and Ortho and paragneisses, Andrelândia domain (6).Towns: Juiz de Fora (JF); Matias Barbosa (MB). identified in the study area. The early one $\left(\mathrm{M}_{1}\right)$ is recorded only in the pre-1.8 granulites, i.e., in all of the orthogranulites of the Juiz de Fora Complex, including leucosomes and paleosomes of migmatitic gneisses. Such rocks show a granoblastic mineral fabric and granulite facies parageneses (orthopyroxene \pm clinopyroxene + plagioclase + orthoclase + quartz \pm hornblende), which are clearly prior to the Brasiliano-Panafrican-related penetrative foliation (Figs. 4B and 4C). Thermometry data indicate Mj thermal peak conditions around » 800 $-895^{\circ} \mathrm{C}$ and chemical composition of granulite facies amphiboles point to $\mathrm{Mj}$ low to intermediate (?) pressure conditions (Duarte 1998). Overall, a $M_{l}$ passive metamorphism resulted from the heat and CO fluids, possibly released during an extensional event by underplated basic magma, related to a Paleoproterozoic (Transamazonian) or Mesoproterozoic event. An anti-clockwise P-T-t path of $\mathrm{M}_{1}$ metamorphism is proposed on the basis of these observations.

The late metamorphic event $\left(\mathrm{M}_{2}\right)$ can be identified in all the orthogneisses and paragneisses of the JFD, being associated to the main phase of deformation. This is characterized by the growth of its mineral parageneses within the penetrative foliation. Temperature and/ or fluid pressure gradients occur within the JFD. For instance, the metasedimentary rocks record dehydration reactions, turning them to granulite facies paragneisses, whereas retrogressive hydration reactions along the main foliation and shear zones appear in the Juiz de Fora Complex orthogranulites (Figs. 4C). Garnet coronas around pyroxenes and $\mathrm{M}_{2}$-related hornblendes record the latest stages of $\mathrm{M}_{2}$ metamorphism in the Juiz de Fora Complex (Figs. 4D and 4E). The pelitic gneisses (s.s.) of the JFD did hardly develop metamorphic facies diagnostic parageneses. However, the relatively more immature pelitic gneisses (semipelitic types) show $\mathrm{M}_{2}$ orthopyroxene-bearing mineral parageneses (Fig. 4F) and there is evidence of vapor-absent partial melting process generated by the breakdown of biotite. Products of this process are the observed leucosomes and the Salvaterra Charnoenderbite plutonic body. Geothermobarometry supports field and petrographic data and shows that $\mathrm{M}$ evolved under the following conditions: Temperature $>700-750^{\circ} \mathrm{C}$, pressure between 6 and $7 \mathrm{~Kb}$ and gradients of fluid $\left(\mathrm{H}_{2} \mathrm{O}\right)$ pressure (Duarte 1998). A clockwise P-T$\mathrm{t}$ path, associated with compression and thrust tectonism, is proposed for the evolution of the $\mathrm{M}_{2}$ metamorphic event (Duarte and Heilbron 1999).

CONCLUSION Three different petrological types of granulite/ charnockite occur within the Juiz de Fora Domain in the central segment of the Ribeira Belt. The pre-1.8 rocks are orthogranulites of the Juiz de Fora Complex and field, petrographic and geothermobarometric data indicate that they were formed by the evolution of a pre-Brasiliano passive metamorphic process $\left(\mathrm{M}_{1}\right)$.
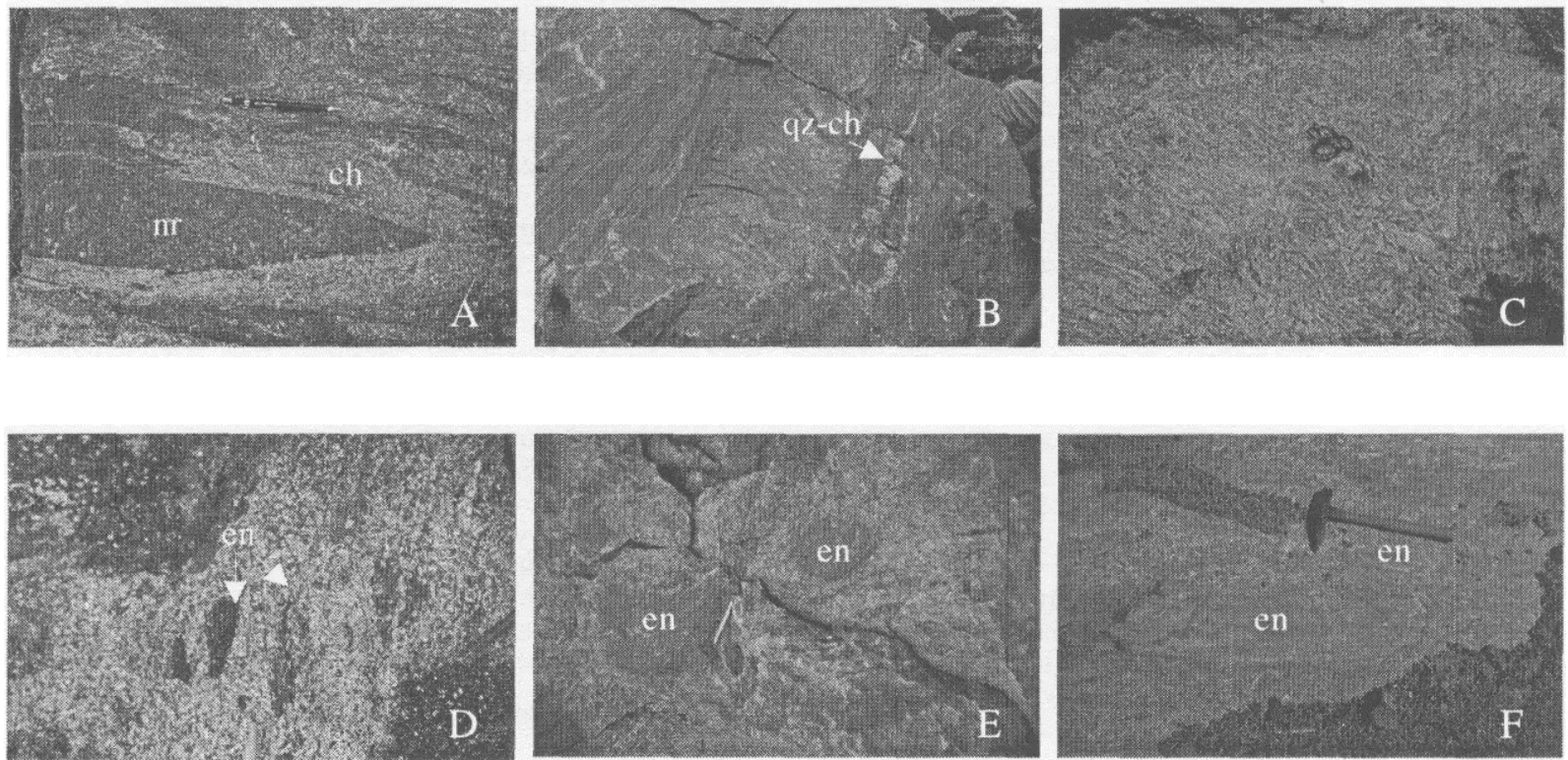

Figure 3- A) Intrusive charnockites (ch) and norites (nr) of Juiz de Fora Complex; B) Banded granulites and intrusive quartz - charnockites (qz-ch) of Juiz de Fora Complex; C) Stromatic migmatite of the metasedimentary unit; D) Diatexite with biotite + garnet enclaves (en); E) Enclaves (en) of Juiz de Fora Complex granulites within the Salvaterra Charno-enderbite; F) Enclaves (en) of calcsilicate rock of the metasedimentary unit within the Salvaterra Charno-enderbite. 
Resultant parageneses contain pyroxenes but no garnet and this is attributed to the low pressures within which this process has evolved. During the Brasiliano-Pan-African Orogeny, the mafic granulites developed orthopyroxene + clinopyroxene + quartz + orthoclase + garnet + hornblende granulite fades parageneses, whereas the intermediate to acid granulites originated hornblende and/or biotite plus the pre-Brasiliano granulite facies metastable mineral phases.

The post-1.8 Ga metasedimentary rocks record high-grade metamorphism only during the Brasiliano-Pan-African Orogeny. Data indicate that metamorphism caused $\mathrm{H}_{2} \mathrm{O}$ to migrate from the metasedimentary rocks to the orthogranulites of the Juiz de Fora Complex.

The Salvaterra Charno-enderbite is interpreted as an autochthonous to parautochthonous igneous body, generated by vapor-absent partial melting of the paragneiss association with minor contributions of orthogranulites of the Juiz de Fora Complex (Duarte et al. 1999). Enclaves are considered as restite portions of the source rocks. Field, petrographic and petrological data indicate that this body was originated during the period of $\mathrm{M}_{2}$ metamorphic peak and thrust tectonism, which characterize the syn-collisional stage (» 565-595 My.; Valladares et al. 2000) of the Panafrican-Brasiliano Orogeny within the central segment of the Ribeira Belt.

Acknowledgements This project was carried out with the support of FAPERJ (Fundacao de Amparo a Pesquisa do Rio de Janeiro). The authors are grateful to Ana Maria Paschoal Duarte who reviewed the text.

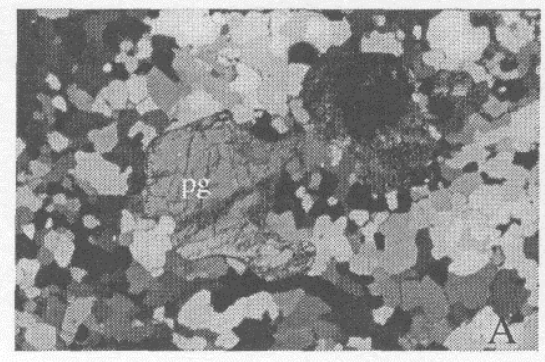

$2 \mathrm{~mm}$

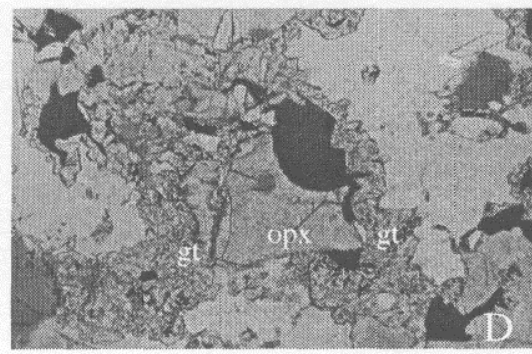

$0,5 \mathrm{~mm}$
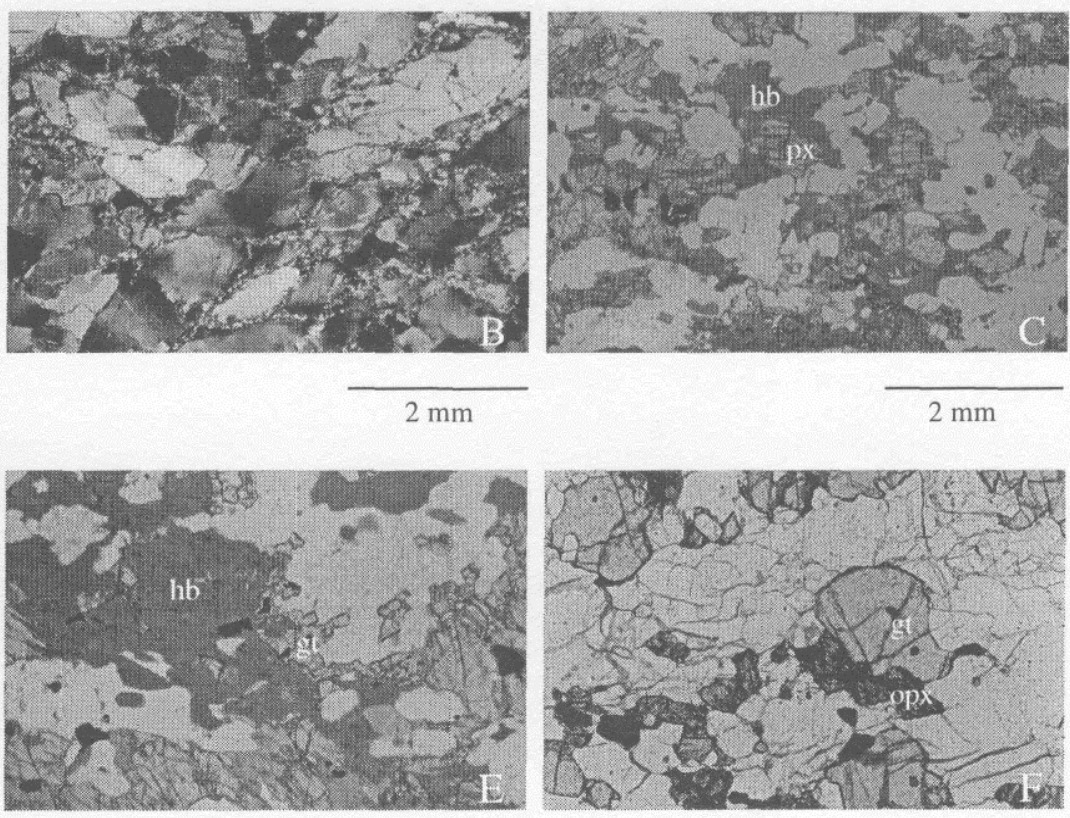

$1 \mathrm{~mm}$

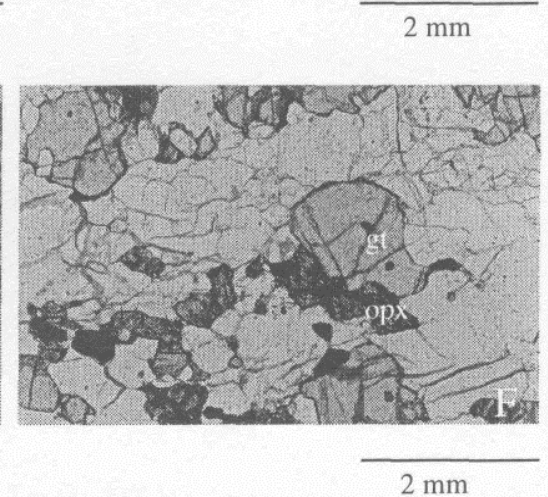

Figure 4- A) Igneous texture of the Salvaterra Charno-enderbite - Corroded plagioclase (pg); B) Pre-Brasiliano granoblastic texture partially obliterated by a Brasiliano mylonitic foliation - Enderbite of the Juiz de Fora Complex; C) Old ortho and clinopyroxenes (px) partially replaced by Brasiliano-oriented hornblende grains (hb) - norite of Juiz de Fora Complex; D) Late garnet corona (gt) around old orthopyroxene grain (opx) - norite of Juiz de Fora Complex; E) Late garnet (gt) at the borders of Brasiliano hornblende grain (hb) - norite of the Juiz de Fora Complex; F) Biotite-garnet (gt)-orthopymxene (opx) gneiss of the metasedimentary unit.

\section{References}

Barbosa A.L. \& Sad J.H.G. 1983a. Reinterpretação das Series Juiz de Fora e Paraiba, em Minas Gerais e no Rio de Janeiro. In: SBG, Simp. Geol. MG., 2, Belo Horizonte, Anais, 1-15.

Barbosa A.L. \& Sad J.H.G. 1983b. Petrografia dos charnockitos e rochas afins ao longo da divisa RJ/MG. In: SBG, Simp. Geol. MG., 2, Belo Horizonte, Anais, 63-74.

Barbosa A.L. \& Sad J.H.G. 1983c. Geoquimica e petrologia dos charnockitos e rochas afins do Complexo Juiz de Fora. RJ/MG. In: SBG, Simp. Geol. MG, 2, Belo Horizonte, Anais, 75-84.

Campos Neto M.C. \& Figueiredo M.C.H. 1990. Evolução geológica dos terrenos Costeiro, Paraíba do Sul e Juiz de Fora (RJ-MG-ES). In: SBG, Congr. Bras. Geol., 36, Natal, Anais, 6:2631-2648.

Campos Neto M.C. \& Figueiredo M.C.H. 1992. A Orogenese Rio Doce. In: SBG, Congr. Bras. Geol., 37, São Paulo, Boletim de Resumos Expandidos, 1:276-277.

Cordani U.G., Delhal J., Ledent O. 1973. Orogeneses superposeés dans le Precambrien du Bresil sud-oriental (Etats du Rio de Janeiro et de Minas Gerais). Rev. Bras. Geoc., 3:1-22.

Duarte B. P. (1998). Evolução Tectonica dos Ortognaisses dos Complexes Juiz de Fora e Mantiqueira na Regiao de Juiz de Fora: Geologia, Petrologia e Geoquimica. IG/USP, Tese de Doutoramento, $284 \mathrm{p}$.

Duarte B. P. \& Heilbron M. 1999. Metamorphic Evolution of the Early to Medium Proterozoic Granulite Facies Rocks of the Central Segment of the BrasilianoPanafrican Ribeira Belt, Southeastern Brazil. Journal of Conference Abstracts, 4: 792.

Duarte B.P., Heilbron M., Campos Neto M. C., Porto Jr. R. 1999. The Garnet Charnockite Plutonic Body of the Juiz de Fora Region, Central Segment of the Pan-AfricanBrasiliano Ribeira Belt, Southeastern Brazil. In: SBG/BA, Simp. Nac. de Estudos Tectonicos, 7, Boletim de Resumos Expandidos. 2:56-57.
Duarte B. P., Nogueira J. R., Heilbron M., Figueiredo, M.C.H. 1994. Geologia da Região Juiz de Fora e Matias Barbosa (MG). In: SBG, Congr. Bras. Geol., 38. Camboriu, Boletim de Resumos, 2:88-90.

Ebert H. 1955. Pesquisas na parte sudeste do estado de Minas Gerais. Relatório de Atividades. In: DNPM, Relatorio Anual do Diretor da Div. Geol. Min., Ano 1954, 79-89.

Figueiredo M.C.H., Campos Neto M.C., Rego, I.T.S.F. 1989. Geoquimica dos terrenos Juiz de Fora, Paraiba do Sul e Costeiro nos estados do Rio de Janeiro e Espirito Santo. In: SBGq-IG/USP, Workshop de Geoquimica Isotcpica, Geocronologia e Litogeoquimica das Regioes Sul e Sudeste do Brasil, Boletim de Resumos, 41-45.

Fonseca M.J.G., Silva Z.C.G., Campos D.A., Tosato, P. 1979. Mapa e texto explicative das folhas Rio de Janeiro, Vitoria e Iguape, na escala de 1:1000000 (SF23, SF24, e SG230). DNPM. Brasilia, 240p.

Grossi Sad J. H. \& Barbosa L. 1985. A origem dos charnockitos e rochas afins da região do Medio Paraiba do Sul, estado do Rio de Janeiro. Contribuições a geologia e petrologia. Boletim Especial da SBG, Niicleo Minas Gerais, 15-28.

Figueiredo M.C.H. \& Campos Neto M.C. 1993. Geochemistry of the Rio Doce Magmatic Arc, Southeastern Brazil. Anais da Acad. Bras. Cienc., 65(supl. 1):63-81.

Heilbron M. 1993. Evolução tectono-metamorfica da sefao Bom Jardim de Minas-MG Barra do Piraf-RJ, setor central da Faixa Ribeira. IG/USP, Tese de Doutoramento, 268p.

Heilbron M. 1995. O Segmento Central da Faixa Ribeira: Sintese Geologica e Ensaio de Evolução Geotectonica. UERJ, Tese de Livre Docencia, 115p.

Heilbron M., Valeriano C.M., Valladares C.S., Machado N. 1995. A orogenese Brasiliana no segmento central da Faixa Ribeira, Brasil. Rev. Bras. Geoc. 25:245-266.

Heilbron M., Valeriano C.M. Valladares C.S, Almeida J.C.H., Tupinambá M., Duarte B.P 1996. The Brasiliano Orogeny (590-520 Ma.) at the Central Segment of Ribeira Belt, SE Brazil. In: SBG, Congr. Bras. Geol., 39, Salvador, Bol. Res. Exp., 6:107-109. 
Heilbron M., Tupinambá M., Almeida J.C.H., Valeriano C.M., Valladares C.S., Duarte B.P. 1998. New constraints on the tectonic organization and structural styles related to the Brasiliano collage of the Central Segment of Ribeira Belt, SE Brazil. In: International Conference on Basement Tectonics, 14, Ouro Preto, Abstracts, 15-17.

Machado N., Valladares C, Heilbron M., Valeriano C. 1996. U-Pb geochronology of the central Ribeira Belt (Brazil) and implications for the evolution of the Brazilian Orogeny. Precambrian Research 79:347-361.

Machado Filho L., Ribeiro M.W., Gonzalez S.R., Schenini C.A., Santos Neto A., Palmeira R.G.B., Pires J.L.; Teixeira W., Castro H.E.F. 1983. In: MME, Projeto RADAMBRASIL Folhas SF-23/24, Rio de Janeiro/Vitória, 1.Geologia, 27-304.

Nogueira J.R. 1994. Relagdes tectonoestruturais e metamórficas entre metasedimentos e ortognaisses em facies granulito na região a sudoeste de Juiz de Fora, MG. IG/UFRJ

Nogueira J. R. Trouw R.A. 1993.Map metamornsmo de uma região a sudoeste de Juiz de Fora, MG. In: Simp. Geolog. de

Minas Gerais, 7, 180-186.
Oliveira M.A.F. 1980. Petrologia das rochas granulúticas da Faixa Paraíba do Sul, Estado de Janeiro e Minas Gerais. IGCE-UNESP, Tese de Livre Docência, 116p.

Oliveira M.A.F. 1981. Granulitos da Faixa Paraíba do Sul: caracteres geoquimicos dos piroxenios e valores geotermometricos. Rev. Bras. Geoc., 11:222-226.

. Bulk Geoc., 12:369-374 Oliveira M.A.F. 1983. As rochas granulíticas da Faixa Paraíba do Sul. Rev. Bras. Geoc.,
13:84-92.
Pinto C.P. 1991. Programa de levantamentos geológicos básicos do Brasil: Folha Lima Duarte. CPRM/MG. Texto Explicative. $212 \mathrm{p}$

Schmitt R.S.. Trouw R.A.J., Van Schmus, W.R. 1999. The characterization of a Cambrian (") $520 \mathrm{Ma}$ ) tectonometamorphic event in the Costeiro Domain of the Ribeira Belt, using U-Pb in syntectonic veins. In: Simpósio Nacional de Estudos Tectônicos. Lençois. Extended Abstracts

Teixeira W. \& Figueiredo M.C.H. 1991. An outline of early Prpterozoic crustal evolution in e São Francisco Craton, Brazil: a review. Precambrian Research 53:1-22

Tupinambá M., Teixeira W., Heilbron M., Basei M. 1998. The Pan-African/Brasiliano arc related magmatism at the Costeiro Domain of the Ribeira Belt, southeastern Brazil new geochronological and lithogeochemical data. In: International Conference on

Basement Tectonics, Ouro Preto, Abstracts, 12-14.
Valladares C., Duarte B.P., Heilbron M., Ragatky D. 2000 - Tectono-magmatic evolution of the Occidental terrane and the Paraiba do Sul Klippe of the Neoproterozoic Ribeira Orogenic belt, southeastern Brazil. Rev. Bras.Geoc. (submmited)

Valladares C., Heilbron M., Machado N Valeriano C. 1997. Provenance of central Ribeira belt metasediments using ${ }^{20} \mathrm{~Pb} /{ }^{206} \mathrm{~Pb}$ ages on zircon by laser - ablation. In: Symp. Isot. Geol. Extended Abstracts, 323-325.

Contribution IGC-142

Received February 2,2000 Accepted for publication April 30,2000 